\title{
The Contribution of Roots, Mycorrhizal Hyphae, and Soil Free-Living Microbes to Soil Respiration and Its Temperature Sensitivity in a Larch Forest
}

\author{
Naoki Makita *, Roma Fujimoto and Azusa Tamura \\ Faculty of Science, Shinshu University, Nagano 390-8621, Japan; makita701@gmail.com (R.F.); \\ azusa3336@gmail.com (A.T.) \\ * Correspondence: macky@shinshu-u.ac.jp
}

Citation: Makita, N.; Fujimoto, R.; Tamura, A. The Contribution of Roots, Mycorrhizal Hyphae, and Soil Free-Living Microbes to Soil Respiration and Its Temperature Sensitivity in a Larch Forest. Forests 2021, 12, 1410. https://doi.org/ 10.3390/f12101410

Academic Editor: Oleg V. Menyailo

Received: 26 September 2021

Accepted: 13 October 2021

Published: 15 October 2021

Publisher's Note: MDPI stays neutral with regard to jurisdictional claims in published maps and institutional affiliations.

Copyright: (C) 2021 by the authors. Licensee MDPI, Basel, Switzerland. This article is an open access article distributed under the terms and conditions of the Creative Commons Attribution (CC BY) license (https:/ / creativecommons.org/licenses/by/ $4.0 /)$.

\begin{abstract}
Soil respiration plays a critical role in driving soil carbon (C) cycling in terrestrial forest ecosystems. However, evidence to demonstrate the response of roots, mycorrhizal hyphae, and soil free-living microbes of soil respiration and their temperature sensitivity $\left(Q_{10}\right)$ remains lacking. Here, we used a root exclusion method to assess the contribution and response of root respiration $\left(\mathrm{R}_{\text {root }}\right)$, mycorrhizal respiration $\left(\mathrm{R}_{\mathrm{myc}}\right)$, and (soil organic matter) SOM respiration $\left(\mathrm{R}_{\text {som }}\right)$ to soil temperature in a larch forest. During the growing period, the contributions of $R_{\text {root }}, R_{\text {myc }}$, and $R_{\text {som }}$ to soil respiration were $42 \%, 6 \%$, and $52 \%$, respectively. The respiration rates of all components increased exponentially with increasing temperature. Based on these constitutive respiration rates with soil temperature, the $Q_{10}$ values for $R_{\text {root }}, R_{\text {myc }}$, and $R_{\text {som }}$ were $3.84,5.18$, and 1.86 , respectively. The results showed that the response to temperature change was different among roots, mycorrhizal hyphae, and microbes in the soil, while the temperature sensitivity of autotrophic respiration was higher than that of heterotrophic respiration. Importantly, the $R_{m y c}$ at this site was extremely sensitive to temperature, although its overall emission was small. Mycorrhizal associations were identified as the key drivers of soil respiration and temperature sensitivity. A good understanding of the different soil $\mathrm{CO}_{2}$ efflux components will provide useful information for determining soil $\mathrm{C}$ fluxes and predicting soil $\mathrm{C}$ dynamics under changing environments.
\end{abstract}

Keywords: autotrophic respiration; heterotrophic respiration; mycorrhiza; mycorrhizal hyphae; $Q_{10}$; rhizosphere respiration; root-exclusion method; soil $\mathrm{CO}_{2}$ efflux; soil temperature

\section{Introduction}

The $\mathrm{CO}_{2}$ emissions in terrestrial ecosystems are mainly derived from soil respiration $\left(R_{\text {soil }}\right)$, which is important for evaluating the net ecosystem carbon $(C)$ balance because it represents the largest global $\mathrm{C}$ flux (75-100 $\mathrm{Pg} \mathrm{C} \mathrm{yr}^{-1}$ ) between ecosystems and the atmosphere [1,2]. This amount is over 10 times that currently produced by fossil fuel combustion. Thus, even a small change in soil respiration could significantly induce increases in atmospheric $\mathrm{CO}_{2}$, with potential feedback to climate change. Therefore, efforts should be made to develop a mechanistic understanding of how temperature and other environmental factors affect the $\mathrm{R}_{\text {soil }}$ rate $[3,4]$.

Temperature sensitivity is an important factor in quantifying the response of $R_{\text {soil }}$ to climate warming [5] and is often referred to as the $Q_{10}$ temperature coefficient, denoting the rate of change in a process caused by increasing the temperature by $10{ }^{\circ} \mathrm{C}$. Experimental studies of $Q_{10}$ related to $R_{\text {soil }}$ have demonstrated that $Q_{10}$ values vary with temperature and soil moisture [5,6]. It has been recognized that $R_{\text {soil }}$ is sensitive to temperature, but many questions regarding the dynamic responses of autotrophic and heterotrophic respiration to temperature changes remain unanswered. In theory, $\mathrm{R}_{\text {soil }}$ is the sum of the autotrophic component produced by roots and the heterotrophic component derived from soil microorganisms that decompose soil organic matter (SOM). Several studies 
have shown that autotrophic respiration is more sensitive to temperature change than heterotrophic respiration $[7,8]$. Thus, the temperature dependency of $R_{\text {soil }}$ varies among different components $[5,9]$.

Recently, the autotrophic component of $R_{\text {soil }}$ was further separated into respiration of the roots and their mycorrhizal symbionts [10]. It is known that plants can normally allocate a substantial fraction (up to $85 \%$ ) of net photosynthesis to belowground and mycorrhizal fungi $[11,12]$. As a result, much of the assimilated $\mathrm{C}$ is respired by mycorrhizal fungi and fungal hyphae [13]. Because more than $80 \%$ of terrestrial plant species are associated with mycorrhizal fungi, we should not ignore the effect of mycorrhizal respiration. Consequently, real root respiration has often been overestimated due to difficulties in separating the root itself from mycorrhizal respiration.

Novel approaches to separate the autotrophic components have developed and enabled us to evaluate mycorrhizal hyphae growth in the soil, while excluding roots. For example, the mesh exclusion method involves the application of nylon meshes with pore sizes that allow the ingrowth of fungal hyphae while excluding roots [14]. Experiments using this method have produced growing evidence to suggest the high contribution of mycorrhizal respiration to $R_{\text {soil }}$ in the forest field [15,16]. Heinemeyer et al. [17] reported a contribution of mycorrhizal respiration to soil respiration of $<25 \%$ in a temperate pine forest. However, such an approach is rarely applied for the evaluation of temperature sensitivity $Q_{10}$ of each component of $R_{\text {soil }}$, especially the mycorrhizal component.

The variability of soil $\mathrm{CO}_{2}$ efflux associated with environmental drivers may also be mediated by the differential metabolic response of microbes, roots, and rhizosphere to moisture and temperature changes [18]. Here, we aimed to evaluate not only total $R_{\text {soil }}$ rates, but also the constructive root, mycorrhizal, and decomposition respiration rates in a larch (Larix kaempferi (Lamb.) Carrière) forest. Larch forests are one of the main vegetation cover types in boreal and cool-temperate forest ecosystems [19]. Our objectives were: (1) to quantify the temporal variation in $R_{\text {soil }}$ during the growing season, (2) to evaluate the relative contributions of heterotrophic and autotrophic respiration to total $R_{\text {soil }}$, and (3) to determine the response of root respiration $\left(\mathrm{R}_{\text {root }}\right)$, mycorrhizal respiration $\left(\mathrm{R}_{\mathrm{myc}}\right)$, and $\mathrm{SOM}$ respiration $\left(\mathrm{R}_{\text {som }}\right)$ to soil temperature in a larch forest.

\section{Materials and Methods}

\subsection{Study Area}

The study site was located on Mt. Iizuna, Nagano, central Japan $\left(36^{\circ} 43^{\prime} \mathrm{N}, 138^{\circ} 9^{\prime} \mathrm{E}\right.$, $1030 \mathrm{~m}$ above sea level), where the annual precipitation is $1262 \mathrm{~mm}$, and the mean annual temperature is $8.4^{\circ} \mathrm{C}$. The site consisted of a planted forest of Larix kaempferi, a deciduous conifer. The age of the forest in 2018 was 61 years, and the average diameter at breast height was $30.0 \mathrm{~cm}$ [20]. The soil type was volcanic ash-derived Andosols. We established a $30 \times 30 \mathrm{~m}^{2}$ plot at the site where L. kaempferi was dominant. The tree density of L. kaempferi in the plot was 616 trees ha ${ }^{-1}$, and the stand basal area was $45 \mathrm{~m}^{2} \mathrm{ha}^{-1}$ [20].

\subsection{Chamber Experimental Design}

Six plots of $2 \times 2 \mathrm{~m}^{2}$ were established. In August 2018, the soil collars were placed randomly at a distance of approximately $100 \mathrm{~cm}$ from the stems in the six plots, as described in detail below. To separate the contribution of each component to $\mathrm{R}_{\text {soil }}$, the mesh-excision method was used to assess the total, root, mycorrhizal, and soil free-living microbial soil respiration, using the protocol proposed by Heinemeyer et al. [15] and Moyano et al. [16]. Three different soil collars (treatment collars) $12 \mathrm{~cm}$ in diameter were installed in the soil. The first type of collar (A) was made of polyvinylchloride. Type A was $5 \mathrm{~cm}$ in height and was inserted $2 \mathrm{~cm}$ into the ground and fixed with two metal sticks. The type-A collar did not interrupt the roots, mycorrhizal, or soil microbial dynamics and growth, which were evaluated as total $R_{\text {soil }}$.

Before the set of other collars (B and C), soil cores $(12 \mathrm{~cm}$ diameter $\times 35 \mathrm{~cm}$ depth for each) were extracted using thin sharp steel corers for long-term ingrowth core experiments. 
The second type of collar (B) was $5 \mathrm{~cm}$ in height, made of polyvinylchloride using a 50-mesh and was inserted into the soil to a depth of $35 \mathrm{~cm}$. The soil collar was covered with nylon fabric of $50-\mu \mathrm{m}$ mesh, allowing the ingrowth of fungal hyphae, but not roots. The soil depth in B-type collars (35 cm depth) prevented the ingrowth of almost all plant roots because most roots are produced up to $30 \mathrm{~cm}$. After the set of type- $\mathrm{B}$ collars, the cored holes were filled using the soils sieved through a $2.0-\mathrm{mm}$ mesh sieve to remove the original roots, soil, and organic matter and divided into $0-10 \mathrm{~cm}, 10-20 \mathrm{~cm}$, and $20-35 \mathrm{~cm}$ soil depths. The third type of collar (C) was made of polyvinylchloride. Type $C$ was the same size as type-B and was installed at the same depth, but they did not have mesh holes, thus preventing the ingrowth of both roots and mycorrhizal hyphae. In other words, the type-C collar was evaluated as SOM respiration $\left(\mathrm{R}_{\mathrm{som}}\right)$ of only the heterotrophic soil free-living microbial community. Respiration fluxes (R) from the root, mycorrhiza, and soil organic matter were estimated from the difference in $\mathrm{CO}_{2}$ efflux values according to the following equation:

- $\quad$ Type- $\mathrm{A}=$ total soil respiration $\left(\mathrm{R}_{\text {soil }}\right)$.

- $\quad$ Type-A - Type-B = root respiration $\left(\mathrm{R}_{\text {root }}\right)$

- $\quad$ Type- $B$ - Type- $C=$ mycorrhizal respiration $\left(\mathrm{R}_{\mathrm{myc}}\right)$

- Type- $\mathrm{C}=$ soil organic matter $(\mathrm{SOM})$ respiration $\left(\mathrm{R}_{\text {som }}\right)$.

\subsection{Respiration Manual Measurement and Calculations}

The respiration measurements began in early May 2019. The $\mathrm{CO}_{2}$ efflux from each soil chamber was measured 1 or 2 times a month during a fixed period 11:00-13:00 daytime. Measurements were conducted using a closed static chamber system fitted with an infrared $\mathrm{CO}_{2}$ analyzer (GMP343; VAISALA, Helsinki, Finland). To minimize errors in the $\mathrm{CO}_{2}$ efflux measurements in the chamber through pressure changes, we designed a chamber with sufficient volume to achieve the steady pressure in the closed chamber. The chamber was closed with a lid that has a small fan to achieve near-perfect headspace mixing. The time for each measurement was set to $360 \mathrm{~s}$. To compensate for air disturbances caused by opening the chamber, the data for the first $60 \mathrm{~s}$ were discarded. The flux measurement was accepted when the determination coefficient of linear regression $\left(R^{2}\right)$ was larger than 0.9 as a function of time.

At the same time as the respiration measurements, soil environmental data were observed. Soil temperatures at $5-\mathrm{cm}$ soil depth were measured using a portable thermometer (AD-5612A, A\&D, Tokyo, Japan). Soil moisture levels at 5-cm soil depth were determined using a portable soil water content sensor (SM150T; Delta-T Devices, Cambridge, UK).

By pooling all measurement data, the variation in respiration rate in response to temperature change was described by an exponential model [21]:

$$
R=\alpha e^{\beta T}
$$

where $R$ is the respiration rate measured at a given temperature (T), and $\alpha$ and $\beta$ are fitting parameters. Parameter $\alpha$ is referred to as respiration rate at $0{ }^{\circ} \mathrm{C}$

, and $\beta$ defines the temperature dependence of the respiration. Then, the respiratory $Q_{10}$. The $Q_{10}$ was used to describe the temperature sensitivity of respiration and was calculated as the proportional increase in the respiration for each $10{ }^{\circ} \mathrm{C}$ rise in temperature. The $Q_{10}$ can be calculated according to:

$$
Q_{10}=e^{10 \beta}
$$

The respiration was not measured between January and April due to snowpack in the winter season. All statistical analyses were performed using R version 3.5.1 software. 


\section{Results}

\subsection{Soil Environmental Factors and Respiration}

The seasonal soil temperature patterns in the plot were observed (Figure 1a). The soil temperature at $5 \mathrm{~cm}$ depth varied seasonally, ranging from $3.4{ }^{\circ} \mathrm{C}$ in December to $21.2{ }^{\circ} \mathrm{C}$ in August during the study period. The soil moisture ranged from 9.2 to $27.1 \%$ (Figure 1b). The seasonal pattern of soil moisture was not as clear as the temperature, but it seemed to peak at the end of the fall. The soil respiration $\left(R_{\text {soil }}\right)$ ranged from 0.7 to $4.4 \mu \mathrm{mol} \mathrm{m}{ }^{-2} \mathrm{~s}^{-1}$ during the study period (Figure $1 \mathrm{c}$ ). $\mathrm{R}_{\text {soil }}$ showed strong seasonality; it was lowest in December and highest in mid-August. Similarly, temporal variation in root respiration $\left(R_{\text {root }}\right)$, mycorrhizal respiration $\left(R_{\text {myc }}\right)$, and SOM respiration $\left(R_{\text {som }}\right)$ could be observed throughout the seasons. Between May and December 2019, the mean percentage of $R_{\text {soil }}$ was $42 \%, 6 \%$, and $52 \%$ in $R_{\text {root }}, R_{\text {myc }}$, and $R_{\text {som }}$, respectively (Figure $1 d$ ). The relative contributions of the different $R_{\text {soil }}$ components varied during the study period. The contribution of $R_{\text {root }}$ to $R_{\text {soil }}$ increased during early summer and fall, while the contribution of $R_{\text {myc }}$ to $R_{\text {soil }}$ did not show any seasonal pattern and remained low throughout the study period. The contribution of $R_{\text {som }}$ to $R_{\text {soil }}$ was highest during spring and winter and lowest during summer.
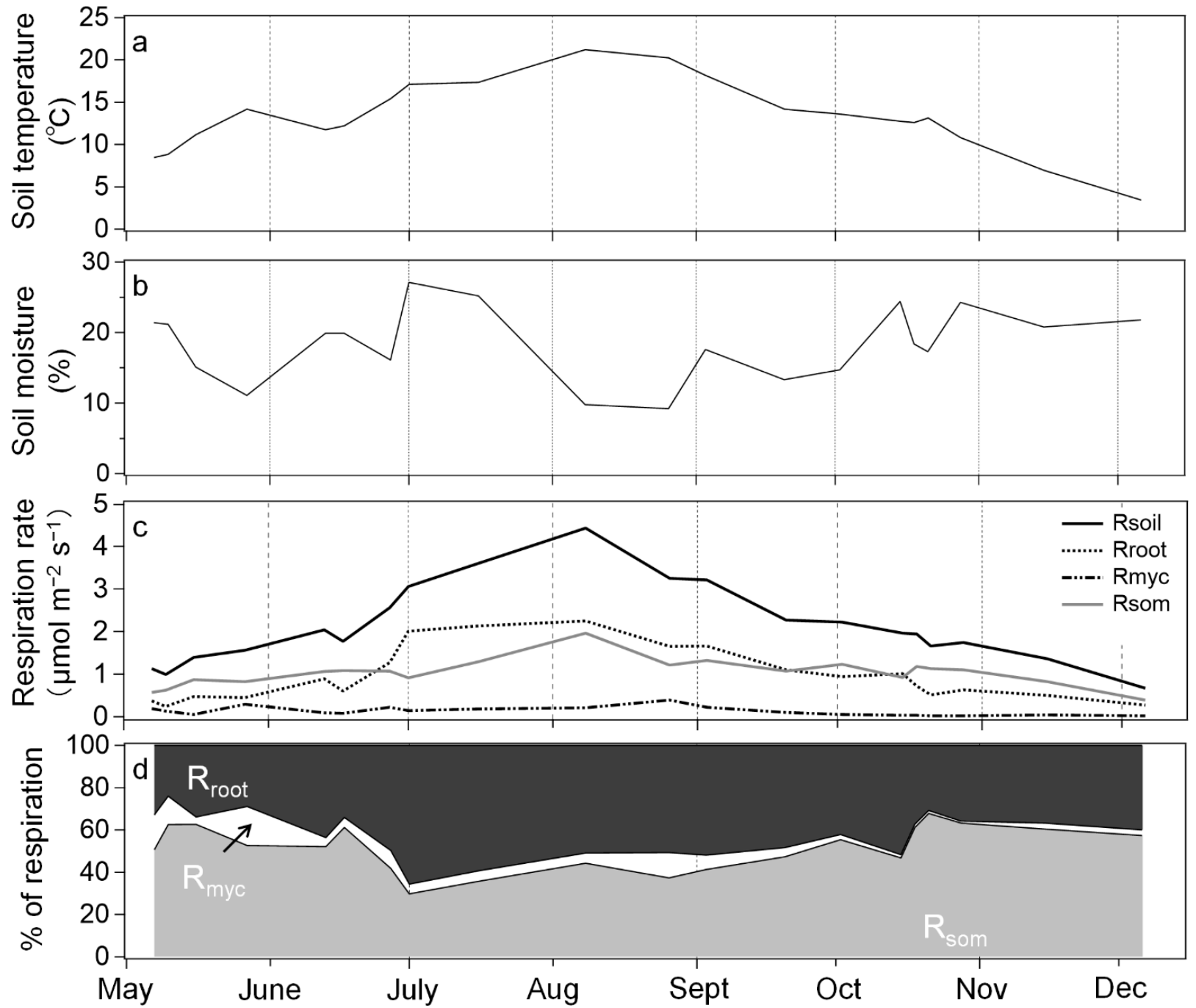

Figure 1. Time courses of (a) soil temperature at $0-5 \mathrm{~cm}$ depth, (b) soil moisture at $0-5 \mathrm{~cm}$ depth, (c) respiration rates in soil, and (d) percentages of different soil respiration components (Root respiration $\left(R_{\text {root }}\right)$, mycorrhizal respiration $\left(R_{\text {myc }}\right)$, and SOM respiration $\left(\mathrm{R}_{\mathrm{som}}\right)$ ) during the months from May to December with non-snowpack period in 2019. 


\subsection{Response of Respiration to Soil Temperature and Moisture}

$\mathrm{R}_{\text {soil }}$ was significantly associated with changes in the measurement temperatures $(p<0.05)$, suggesting an exponential relationship between respiration and temperature (Figure 2a). The $Q_{10}$ value of $R_{\text {soil }}$ during the study period was 2.74 . The estimated parameters for $\mathrm{R}_{\text {soil }}$-temperature are shown in Table 1 . The $\mathrm{R}_{\text {soil }}$ tended to respond linearly to the soil moisture across the study period, although it only explained $7 \%(p>0.05)$ of the variation in $R_{\text {soil }}$ (Figure $2 b$ ). There was no significant linear relationship between $R_{\text {soil }}$ and soil moisture at this site.
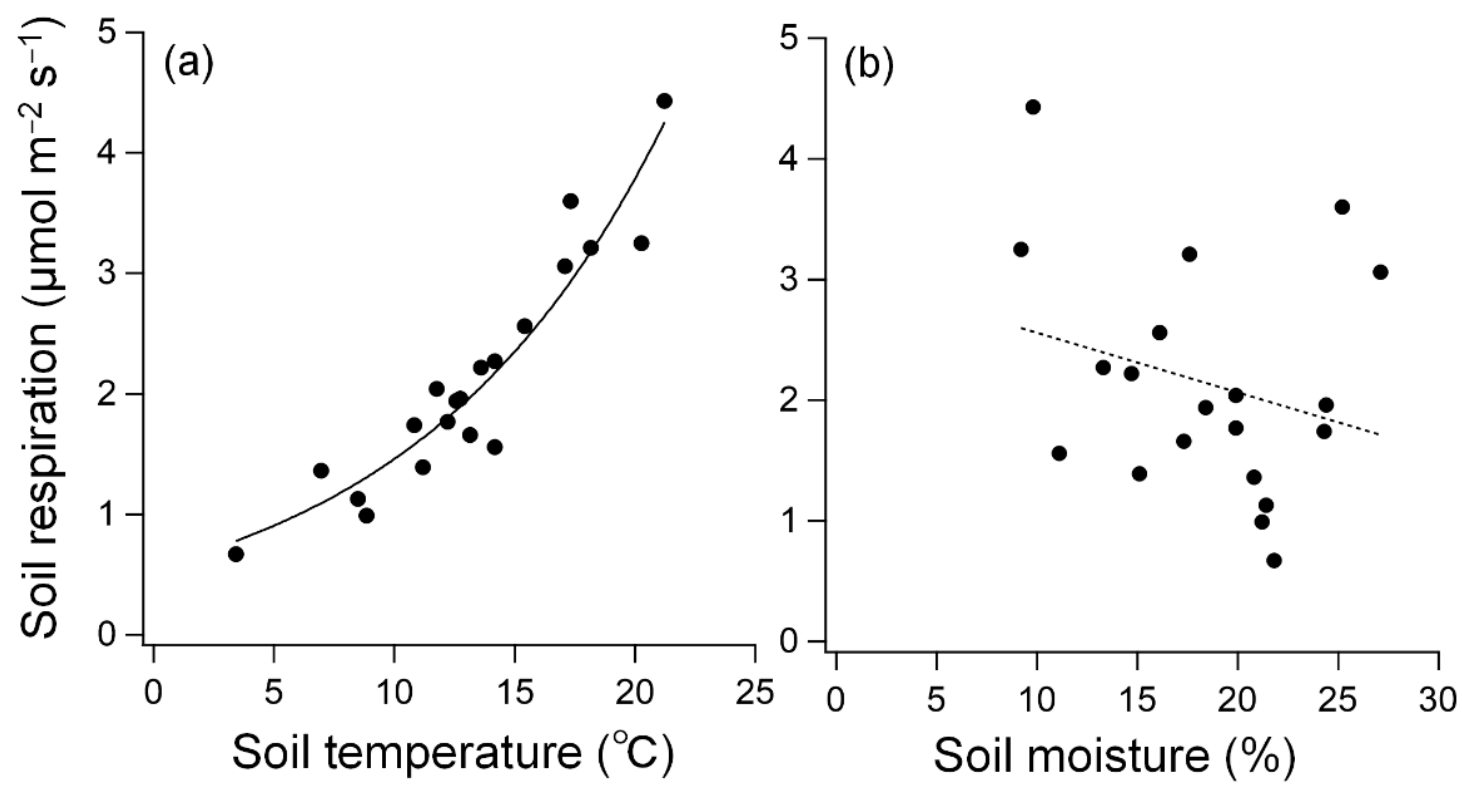

Figure 2. Relationships between soil respiration, (a) soil temperature, and (b) soil moisture in Larix kaempferi forest. Solid line indicates the regression line for all data; $p<0.05$, while a dashed line indicates for all data; $p>0.05$.

Table 1. Estimated parameters ( $\alpha$ and $\beta$ ) and coefficient of determination from Equation (1) for $R_{\text {soil }}$, $\mathrm{R}_{\text {root }}, \mathrm{R}_{\mathrm{myc}}$, and $\mathrm{R}_{\text {som }}$ during growing season in Larix kaempferi forest.

\begin{tabular}{ccccc}
\hline & $\mathbf{R}_{\text {soil }}$ & $\mathbf{R}_{\text {root }}$ & $\mathbf{R}_{\text {myc }}$ & $\mathbf{R}_{\text {som }}$ \\
\hline$\alpha$ & 0.5210 & 0.1346 & 0.0086 & 0.4349 \\
$\beta$ & 0.0998 & 0.1345 & 0.1644 & 0.0618 \\
$\mathrm{R}^{2}$ & 0.89 & 0.78 & 0.55 & 0.64 \\
\hline
\end{tabular}

When different $R_{\text {soil }}$ components were considered, the effect of soil temperature on respiration was significant in the forest $(p<0.001)$. $R_{\text {root }}$ and $R_{\text {myc }}$, markers of autotrophic respiration, increased with increasing soil temperature, with an exponential regression $(p<0.001)$ (Figure 3a,b). Similar to autotrophic respiration, $\mathbf{R}_{\mathrm{som}}$, a heterotrophic respiration was also associated with temperature (Figure $3 c$ ). The $Q_{10}$ values of $R_{\text {root }}, R_{\text {myc }}$, and $R_{\text {som }}$ were $3.84,5.18$, and 1.86 , respectively (Table 1 ). Both $R_{\text {root }}$ and $R_{\text {myc }}$ had higher $Q_{10}$ values than $\mathrm{R}_{\mathrm{som}}$ in this larch forest. 

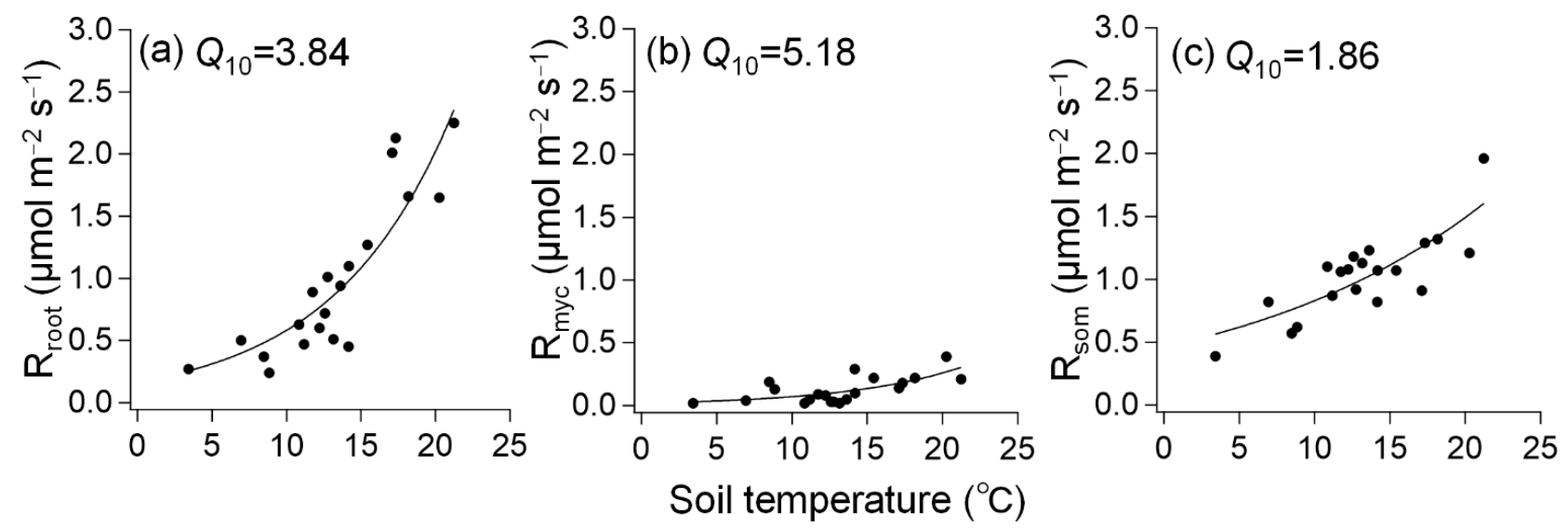

Figure 3. Responses of (a) root respiration $\left(\mathrm{R}_{\text {root }}\right),(\mathbf{b})$ mycorrhizal respiration $\left(\mathrm{R}_{\text {myc }}\right)$, and (c) SOM respiration $\left(\mathrm{R}_{\text {som }}\right)$ to soil temperature in a Larix kaempferi forest. Solid line indicates regression line for all data; $p<0.05$. Temperature sensitivity $\left(Q_{10}\right)$ in each soil respiration components are given in this Figure.

\section{Discussion}

We assessed the contribution of different $R_{\text {soil }}$ components in a mature larch forest. The mean contribution of soil autotrophic respiration $\left(R_{\text {root }}+R_{\text {myc }}\right)$ to $R_{\text {soil }}$ was $48 \%$, suggesting that soil autotrophic respiration was slightly lower than heterotrophic respiration. This finding agrees with estimates in other larch forests. For example, Liang et al. [22] reported that the contribution of autotrophic and heterotrophic components was approximately $43 \%$ and $57 \%$ in a larch plantation in northern Japan. Teramoto et al. [23] estimated that autotrophic and heterotrophic components in a larch plantation in central Japan accounted for $18 \%$ and $82 \%$ of $R_{\text {soil, }}$, respectively. Heterotrophic respiration is a crucial component of soil $\mathrm{CO}_{2}$ efflux associated with the mineralization of dead organic matter via metabolism by fungi and bacteria $[24,25]$. The $R_{\text {som }}$ from the soil surface has been

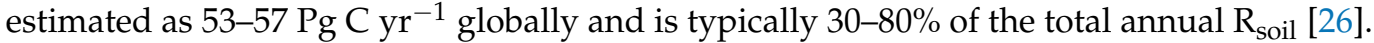
We confirmed the relatively large contribution of $R_{\text {som }}$ to $R_{\text {soil }}$ in this forest species and the important role of microbial decomposition activity for $R_{\text {som }}$ in our forest.

We found that soil autotrophic respiration, including $R_{\text {root }}$ and $R_{\text {myc }}$, was highly variable and showed seasonal patterns (Figure 1d). In our study, soil autotrophic respiration accounted for approximately $55-70 \%$ between late June and early September, which might be due to the $C$ substrate from plant photosynthesis activity. Shoot $C$ assimilation rates are strongly correlated with belowground $C$ allocation to roots and mycorrhizae $[17,27,28]$. Additionally, belowground growth in deciduous species is assumed to peak early in the growing season and is correlated with aboveground growth [29]. When a pulse of root and mycorrhizal growth occurs to support leaf production, the respiring tissue and rhizosphere $\mathrm{CO}_{2}$ efflux are simultaneously increased. Indeed, the larch shoot at our site expanded from May, when the plants grew rapidly. Soil autotrophic respiration might reflect a combination of phenological timing of leaf development in spring and leaf senescence and abscission in autumn and seasonal root and mycorrhizal hyphae growth variations.

Importantly, $R_{\text {myc }}$ accounted for $6 \%$ of total $R_{\text {soil }}$, although the contribution of $R_{\text {myc }}$ was lower than that of $R_{\text {root }}$ at this site. Moyano et al. [30] evaluated $R_{\text {myc }}$ in beech and spruce forests and found that $R_{\text {root }}$ contributed $45 \%$ and $R_{\text {myc }}$ contributed $5 \%$ to $R_{\text {soil }}$, which is similar to our results. On the other hand, Heinemeyer et al. [17] measured $R_{\text {soil }}$ separation in Pinus sylvestris and found contributions to total $R_{\text {soil }}$ of $10 \%$ in $R_{\text {root }}$ and $25 \%$ in $R_{m y c}$, with higher values for $R_{m y c}$ contribution. A large fraction of the $C$ translocated belowground is allocated to the mycorrhizal hyphae [14]. The production of mycorrhizal hyphae is known to change with the type and infection rate of mycorrhizal fungi symbiotic with the root system [31]. Although our study did not determine the type and infection rate of mycorrhizal fungi, it is believed that the mycorrhizal fungal community structure is 
similar to that of Moyano et al. [30]. A qualitative assessment of mycorrhizal fungal species and infection rates is needed to understand the contribution and variability of $R_{m y c}$.

For the heterotrophic component, $R_{\text {som }}$ accounted for most (52-67\%) of $R_{\text {soil }}$ in early spring and late autumn (Figure 1d), probably because of increases in decomposition activity for spring thaw and autumn litter accumulation. The high contribution of $R_{\text {som }}$ in a deciduous forest in specific seasons could also be related to the high input of litter during autumn and the high $C$ availability for microbial decay during soil wetting in spring. Therefore, seasonal variation in litter accumulation and its decomposition may affect $\mathrm{CO}_{2}$ production through microbial physiology during the growing season.

During the growing season in this study, $\mathrm{R}_{\text {soil }}$ increased exponentially with soil temperature (Figure 2a). The temperature sensitivity in this study was consistent with that reported in many previous studies [32]. Our $Q_{10}$ value at $R_{\text {soil }}$ was 2.7 and well within the global median of 2.4 [33] and the range (2.0-6.3) reported for European and North American forest ecosystems $[5,6]$. The $Q_{10}$ values in previous studies of larch forests also ranged from to $2.3-3.1[22,23,34]$. This suggests that the temperature sensitivity of the $R_{\text {soil }}$ rate at our site had ecological characteristics similar to those of larch forests in previous studies.

Focusing on each constitutive respiration rate with soil temperature, $R_{\text {root }}, R_{\text {myc }}$ and $\mathrm{R}_{\text {som }}$ also showed an exponential increasing relationship with temperature (Figure 3 ). Based on these relationships, the $Q_{10}$ values for $R_{\text {root }}, R_{\text {myc }}$, and $R_{\text {som }}$ were $3.84,5.18$, and 1.86 , respectively. The results showed that the response to temperature change was different among roots, mycorrhizal hyphae, and microbes in the soil, and the temperature sensitivity of autotrophic respiration was higher than that of heterotrophic respiration, according to previous studies $[3,7,26]$. Furthermore, the $R_{\mathrm{myc}}$ at this site had to be extremely sensitive to temperature, although the overall emission was small. One possible reason for the high temperature sensitivity of $R_{\text {myc }}$ might be that mycorrhizal component enhance the availability of substrate and its allocation to belowground sinks along the temperature gradients. Consequently, most of the previous studies on $Q_{10}$ of $R_{\text {root }}$ under the field have been overestimated, because they are usually included in the autotrophic flux component when derived from separating $R_{\text {myc }}$ from $R_{\text {root }}$ without further partitioning.

In this study, we used an approach to separate $R_{\text {myc }}$ from $R_{\text {root }}$ under field conditions using ingrowth bags of different mesh sizes, allowing only the ingrowth of fungal hyphae or the roots and fungal hyphae. Using this method, the net effect of mycorrhizal hyphae on $\mathrm{CO}_{2}$ flux was evaluated. However, technical problems in the methodology for evaluating $R_{\text {myc }}$ separation from $R_{\text {root }}$ are still debated [35]. For example, $R_{\text {myc }}$ resulted from the combination of the growth and mortality of mycorrhizal hyphae in mesh bags. Thus, the observed effluxes from mycorrhizal hyphae may depend on the incubation time in the mesh bags through the biomass and turnover rates of hyphae. Nevertheless, we emphasize the potential high $Q_{10}$ of $R_{\text {myc }}$ to soil temperatures in this forest. Future advances in techniques, considering the separation of roots and mycorrhizal biomass and turnover, could elucidate the accurate response of forest soil $C$ sequestration and $C$ fluxes to temperatures.

The relationship between $R_{\text {soil }}$ and soil moisture suggested a negative relationship, but this was not significant (Figure 2b). Liang et al. [22] showed that root respiration in larch was reported to have no clear correlation with moisture content. In contrast, Heinemeyer et al. [17] showed that autotrophic respiration was not significantly affected by changes in soil temperature but was strongly affected by soil moisture. Thus, previous studies have not provided a unified view of soil moisture; therefore, further research is needed for data accumulation across tree species and ecosystems.

In this study, the actual components of $R_{\text {soil }}$ in larch forests were observed. The contributions of $R_{\text {root}}, R_{\text {myc }}$, and $R_{\text {som }}$ to soil respiration was $42 \%, 6 \%$, and $52 \%$, respectively. The respiration rates of all components increased exponentially with increasing temperature. The temperature sensitivity $Q_{10}$ of respiration for each component was high for $R_{\text {root }}$ and $R_{\text {myc }}$ and low for $R_{\text {som }}$. In particular, the temperature sensitivity of $R_{\text {myc }}$ was extremely high, although the amount released was not. The results of this study emphasize the role 
of the mycorrhizal strategy in the ecosystem response to climate temperature for $R_{\text {soil }}$ in forest soils.

Future increases in temperature could generate potential positive feedback between climate warming and soil C flux in forest ecosystems. Most empirical models of soil C dynamics have primarily focused on total $\mathrm{R}_{\text {soil }}$ or $\mathrm{SOM}$ fraction decomposition, implying an over- or underestimation of the soil $C$ flux and soil $C$ sequestration [36]. This is because empirical models often do not include the temperature sensitivity of constructive components such as $R_{\text {root }}, R_{\mathrm{myc}}$, and $R_{\text {som }}$. In particular, $R_{\text {myc }}$ has a relatively higher temperature sensitivity, with major consequences for the current models of $C$ dynamics in the larch forest. A good understanding of the different soil $\mathrm{CO}_{2}$ efflux components will provide useful information for modeling soil $\mathrm{C}$ fluxes and predicting soil $\mathrm{C}$ dynamics in a future climate.

Author Contributions: N.M.: planned and performed the experiments, analyzed the data, wrote the paper, and prepared it for submission; R.F.: planned and performed the experiments, analyzed the data, and wrote the paper; A.T. performed the experiments and analyzed the data. All authors have read and agreed to the published version of the manuscript.

Funding: This research was funded by the Environment Research and Technology Development Fund (JPMEERF20182R03) of the Environmental Restoration and Conservation Agency of Japan.

Institutional Review Board Statement: Not applicable.

Informed Consent Statement: Not applicable.

Data Availability Statement: The data presented in this study are available on request from the corresponding author.

Acknowledgments: The authors would like to thank M. Kuribayashi and staff members of the Nagano Environmental Conservation Research Institute for their helpful support in field experiments.

Conflicts of Interest: The authors declare no conflict of interest.

\section{References}

1. Bond-Lamberty, B.; Thomson, A. A global database of soil respiration data. Biogeosciences 2010, 7, 1915-1926. [CrossRef]

2. Bond-Lamberty, B.; Thomson, A. Temperature-associated increases in the global soil respiration record. Nature 2010, 464, 579-582. [CrossRef] [PubMed]

3. Epron, D.; Dantec, V.L.; Dufrene, E.; Granier, A. Seasonal dynamics of soil carbon dioxide efflux and simulated rhizosphere respiration in a beech forest. Tree Physiol. 2001, 21, 145-152. [CrossRef]

4. Savage, K.; Davidson, E.A.; Tang, J. Diel patterns of autotrophic and heterotrophic respiration among phenological stages. Glob. Chang. Biol. 2013, 19, 1151-1159. [CrossRef] [PubMed]

5. Janssens, I.A.; Pilegaard, K. Large seasonal changes in $Q_{10}$ of soil respiration in a beech forest. Glob. Chang. Biol. 2003, 9, 911-918.

6. Davidson, E.A.; Belk, E.; Boone, R.D. Soil water content and temperature as independent or confounded factors controlling soil respiration in a temperate mixed hardwood forest. Glob. Chang. Biol. 1998, 4, 217-227. [CrossRef]

7. Boone, R.D.; Nadelhoffer, K.J.; Canary, J.D.; Kaye, J.P. Roots exert a strong influence on the temperature sensitivity of soil respiration. Nature 1998, 396, 570-572.

8. Zhou, T.; Shi, P.J.; Hui, D.F.; Luo, Y.Q. Global pattern of temperature sensitivity of soil heterotrophic respiration $Q_{10}$ and its implications for carbon-climate feedback. J. Geophys. Res. Biogeosci. 2009, 114, 9. [CrossRef]

9. Davidson, E.A.; Janssens, I.A. Temperature sensitivity of soil carbon decomposition and feedbacks to climate change. Nature 2006, 440, 165-173. [CrossRef] [PubMed]

10. Hughes, J.K.; Hodge, A.; Fitter, A.H.; Atkin, O.K. Mycorrhizal respiration: Implications for global scaling relationships. Trends Plant Sci. 2008, 13, 583-588. [CrossRef]

11. Franklin, O.; Näsholm, T.; Högberg, P.; Högberg, M.N. Forests trapped in nitrogen limitation-An ecological market perspective on ectomycorrhizal symbiosis. New Phytol. 2014, 203, 657-666. [CrossRef] [PubMed]

12. Ficken, C.D.; Warren, J.M. The carbon economy of drought: Comparing respiration responses of roots, mycorrhizal fungi, and free-living microbes to an extreme dry-rewet cycle. Plant Soil 2019, 435, 407-422. [CrossRef]

13. Talbot, J.M.; Allison, S.D.; Treseder, K.K. Decomposers in disguise: Mycorrhizal fungi as regulators of soil C dynamics in ecosystems under global change. Funct. Ecol. 2008, 22, 955-963. [CrossRef]

14. Wallander, H.; Ekblad, A.; Godbold, D.L.; Johnson, D.; Bahr, A.; Baldrian, P.; Björk, R.G.; Kieliszewska-Rokicka, B.; Kjøller, R.; Kraigher, H.; et al. Evaluation of methods to estimate production, biomass and turnover of ectomycorrhizal mycelium in forests soils-A review. Soil Biol. Biochem. 2013, 57, 1034-1042. [CrossRef] 
15. Heinemeyer, A.; Ineson, P.; Ostle, N.; Fitter, A.H. Respiration of the external mycelium in the arbuscular mycorrhizal symbiosis shows strong dependence on recent photosynthates and acclimation to temperature. New Phytol. 2006, 171, 159-170. [CrossRef]

16. Moyano, F.E.; Kutsch, W.L.; Schulze, E.D. Response of mycorrhizal, rhizosphere and soil basal respiration to temperature and photosynthesis in a barley field. Soil Biol. Biochem. 2007, 39, 843-853. [CrossRef]

17. Heinemeyer, A.; Hartley, I.P.; Evans, S.P.; De la Fuente, J.A.C.; Ineson, P. Forest soil $\mathrm{CO}_{2}$ flux: Uncovering the contribution and environmental responses of ectomycorrhizas. Glob. Chang. Biol. 2007, 13, 1786-1797. [CrossRef]

18. Heinemeyer, A.; Wilkinson, M.; Vargas, R.; Subke, J.A.; Casella, E.; Morison, J.I.L.; Ineson, P. Exploring the "overflow tap" theory: Linking forest soil $\mathrm{CO}_{2}$ fluxes and individual mycorrhizosphere components to photosynthesis. Biogeosciences 2012, 9, 79-95. [CrossRef]

19. Mamet, S.D.; Brown, C.D.; Trant, A.J.; Laroque, C.P. Shifting global Larix distributions: Northern expansion and southern retraction as species distributions: Northern expansion and southern retraction as species respond to changing climate. J. Biogeogr. 2019, 46, 30-44. [CrossRef]

20. Ozeki, M.; Kuribayashi, M. Tree growth of old man-made larch stands in lizuna Heights, Ngano Prefecture, central Japan. Bull. Nagano Environ. Conserv. Res. Inst. 2019, 15, 45-49, (In Japanese with English summary).

21. Lloyd, J.; Taylor, J.A. On the temperature dependence of soil respiration. Funct. Ecol. 1994, 8, 315-323. [CrossRef]

22. Liang, N.; Hirano, T.; Zheng, Z.M.; Tang, J.; Fujimura, Y. Soil $\mathrm{CO}_{2}$ efflux of a larch forest in northern Japan. Biogeosciences 2010, 7, 3447-3457. [CrossRef]

23. Teramoto, M.; Liang, N.; Takahashi, Y.; Zeng, J.; Saigusa, N.; Ide, R.; Zhao, X. Enhanced understory carbon flux components and robustness of net $\mathrm{CO}_{2}$ exchange after thinning in a larch forest in central Japan. Agric. For. Meteorol. 2019, 274, 106-117. [CrossRef]

24. Harmon, M.E.; Bond-Lamberty, B.; Tang, J.W.; Vargas, R. Heterotrophic respiration in disturbed forests: A review with examples from North America. J. Geophys. Res. Biogeosci. 2011, 116, 1-17. [CrossRef]

25. Kominami, Y.; Jomura, M.; Ataka, M.; Tamai, K.; Miyama, T.; Dannoura, M.; Makita, N.; Yoshimura, K. Heterotrophic respiration causes seasonal hysteresis in soil respiration in a warm-temperate forest. J. For. Res. 2012, 17, 296-304. [CrossRef]

26. Bond-Lamberty, B.; Wang, C.; Gower, S.T. A global relationship between the heterotrophic and autotrophic components of soil respiration? Glob. Chang. Biol. 2004, 10, 1756-1766. [CrossRef]

27. Vargas, R.; Baldocchi, D.D.; Allen, M.F.; Bahn, M.; Black, T.A.; Collins, S.L.; Yuste, J.C.; Hirano, T.; Jassal, R.S.; Pumpanen, J.; et al. Looking deeper into the soil: Biophysical controls and seasonal lags of soil $\mathrm{CO}_{2}$ production and efflux. Ecol. Appl. 2010, 20, 1569-1582. [CrossRef] [PubMed]

28. Makita, N.; Kosugi, Y.; Sakabe, A.; Kanazawa, A.; Ohkubo, S.; Tani, M. Seasonal and diurnal patterns of soil respiration in an evergreen coniferous forest: Evidence from six years of observation with automatic chambers. PLoS ONE 2018, 13, e0192622.

29. Newman, G.S.; Arthur, M.A.; Muller, R.N. Above- and belowground net primary production in a temperate mixed deciduous forest. Ecosystems 2006, 9, 317-329. [CrossRef]

30. Moyano, F.E.; Kutsch, L.W.; Rebmann, C. Soil respiration fluxes in relation to photosynthetic activity in broad-leaf and needle-leaf forest stands. Agric. For. Meteorol. 2008, 148, 135-143. [CrossRef]

31. Ekblad, A.; Wallander, H.; Godbold, D.L.; Cruz, C.; Johnson, D.; Baldrian, P.; Bjork, R.G.; Epron, D.; Kieliszewska-Rokicka, B.; Kjoller, R.; et al. The production and turnover of extramatrical mycelium of ectomycorrhizal fungi in forest soils: Role in carbon cycling. Plant Soil 2013, 366, 1-27. [CrossRef]

32. Hamdi, S.; Moyano, F.; Sall, S.; Bernoux, M.; Chevallier, T. Synthesis analysis of the temperature sensitivity of soil respiration from laboratory studies in relation to incubation methods and soil conditions. Soil Biol. Biochem. 2013, 58, 115-126. [CrossRef]

33. Raich, J.W.; Schlesinger, W.H. The global carbon dioxide flux in soil respiration and its relationship to vegetation and climate. Tellus 1992, 44, 81-99. [CrossRef]

34. Liang, N.; Nakadai, T.; Hirano, T.; Qu, L.; Koike, T.; Fujinuma, Y.; Inoue, G. In situ comparison of four approaches to estimating soil $\mathrm{CO}_{2}$ efflux in a northern larch (Larix kaempferi Sarg.) forest. Agr. For. Meteorol. 2004, 123, 97-117. [CrossRef]

35. Neumann, J.; Matzner, E. Contribution of newly grown extrametrical ectomycorrhizal mycelium and fine roots to soil respiration in a young Norway spruce site. Plant Soil 2014, 378, 73-82. [CrossRef]

36. Reichstein, M.; Janssens, I.A. Semi-empirical modeling of the response of soil respiration to environmental factors in laboratory and field conditions. In Soil Carbon Dynamics: An Integrated Methodology; Kutsch, W.L., Michael, B., Heinemeyer, A., Eds.; Cambridge University Press: Cambridge, UK, 2009; pp. 207-220. 